\title{
Confessions of a biologist
}

Sydney Brenner

A Slot Machine, A Broken Test Tube:

An Autobiography. By S.E. Luria.

Harper \& Row: 1984. Pp.228. \$17.95. To

be published in the UK on

31 May, £12.50.

AN autobiography allows a man the opportunity to tell all about his life and work, to reveal his secret motives and ambitions, and to give a personal view of the world and the people he has known in it. For many scientists, total self-revelation might be almost indecent; there is the professional stance of objectivity and rationality and, more to the point, there is that stuffy, critical audience of colleagues. Scientists are second only to politicians in taking themselves very seriously and in erecting deeply boring literary monuments to themselves. Perhaps only the old and very accomplished, who no longer care what people think of them, and, possibly, the slightly mad, who don't mind, can write provokingly about themselves. The reason why Jim Watson's The Double Helix is a marvellous book is not that it demystified the historical process of the scientific endeavour, as has been said, but rather that it tempered the drama with high comedy and, at the end, the person who emerged as the worst (as well as the best) was the author himself.

Salvador Luria, Sedgwick Professor of Biology at the Massachusetts Institute of Technology, would agree with most of this, and he sets the challenge in the preface: "I have found most biographies of scientists remarkably uninteresting and their autobiographies even more so". The book he has written is deliberately personal - a confessional account of himself and his scientific, political, literary and other interests. The treatment is not chronological and the author explains that he is replacing this by a developmental approach which he sees in existential terms, the self defining itself by creative acts of will in response to the outside world. Indeed, in the preface the reader will find a theory not only of life but also of meta-life, or autobiography.

However, the most interesting part of the book is the story of Luria's early years. He was born in 1912 in Turin, Italy, into a branch of one of the oldest Jewish families. A contemporary at school was Ugo Fano who later become a physicist and played an important role in Luria's life in giving him Max Delbrück's papers to read; I did not realize that Luria knew of Delbrück before he went to America. Luria studied medicine, spent some time in Rome, left Italy for France in 1938 and escaped to America in 1940. It is a great pity that he devotes only 19 pages of the book to this period during which Italy and Europe underwent cataclysmic political and social changes. I would have liked to have heard more about this time of his life; given his avowed existentialist views, he should have told us more about the formative years instead of merely flitting through them. Indeed, the remainder of the historical narrative is treated in the same brief manner, and is like an abstract of an autobiography rather than the book itself.

The middle part, "The Science Path", describes his scientific work and development. All elderly molecular geneticists know of the Luria-Delbrück fluctuation experiment which proved that mutants pre-exist in bacterial cultures and do not depend on exposure to the agent used to select them. The experiment consists in measuring the variation of mutant frequency in independent experiments. Luria recounts how he got the idea at a faculty dance at Indiana University in 1943 by watching someone using a slot machine (one reference to the title

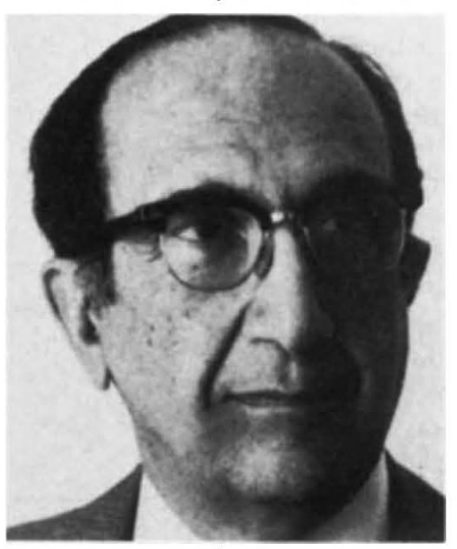
The remainder of the book is about Luria's interest in literature, especially poetry, his commitment to politics and his emotional development, each considered separately, as examples of his sectorial theory of autobiography.

I found the book disappointing. Although not a contemporary, I know many of the protagonists and have lived through many of the events in science; I also know Luria and over the years have naturally formed my own opinion of him. Perhaps, like writers of autobiographies, reviewers need to be open and divulge their private judgements. There is a sense in which this book might be even more self-revealing than the author intended. There is the Luria described, but there is also Luria the describer - a man with confident, if somewhat ponderous, judgements on all matters, noisy, irritable, egocentric. Who else could have written the following after a reference to literature classes he conducted for science students at home?

of this book). The experiment was intended to refute the views of Sir Cyril Hinshelwood who did not believe in genes or mutation but only in chemical equilibria. I happen to know it did not convince him at all, because I spent several months at Oxford in 1952 and 1953 doing enough fluctuation experiments to prove to Sir Cyril that the results could not be explained by dirty test tubes. The broken test tube of the title also refers to another of Luria's experiments which led him to the discovery of the restriction phenomenon, research which has had a great impact.

\section{African ancestors}

\section{C.K. Brain}

One Life: An Autobiography.

By Richard E. Leakey.

Michael Joseph: 1984. Pp.207. £10.95.

TO HAVE been born into the Leakey family of East Africa meant that, from birth, one was immersed in African antiquity, fossils and discussion of human origins. Understandably enough, Richard Leakey's first reaction was to distance himself from things academic and from the research activities of his illustrious parents, Louis and Mary. But the allure of fossil man drew him back, urging him to make a unique contribution to palaeoanthropology, on his own terms, and free of his father's shadow. How this was achieved is the story of Richard Leakey's life, related here with freshness and excitement which makes most enjoyable reading.
Some time ago I received a note from a former M.I.T. student who had been in one of my classes. She reminded me that when she had told me she was planning to spend the summer after graduation learning more biochemistry I suggested that instead she read Virginia Woolf. She claims that she did follow my advice, with the result that instead of chemistry she went into business administration. Shadows of Bloomsbury! Maybe she will be another John Maynard Keynes.

Sydney Brenner is a member of the scientific staff of the Medical Research Council's Laboratory of Molecular Biology, Cambridge.

The road to personal discovery started in 1963 when, at the age of 19, Richard was piloting a light aircraft over the rift valley to Olduvai Gorge. Along the west side of Lake Natron he saw exposures of promising-looking sediments and before long returned to the place to establish that fossils could indeed be found in abundance there. With help from his father's National Geographic Society grant, he organized several expeditions to this Peninj site, accompanied by Glynn Isaac, who was to become codirector of the later Koobi Fora project, and Kamoya Kimeu, who in time established himself as Kenya's foremost fossilcollector. This fieldwork produced a spectacular mandible of Australopithecus boisei, the first lower jaw of this hominid to be found in East Africa.

Richard's big chance to exercise his organizational skill came three years later, when a joint American-French-Kenyan expedition involving Clark Howell, Camille Arambourg and Louis Leakey went to the Omo valley in Ethiopia. Louis Leakey dele- 